NBER WORKING PAPER SERIES

\title{
BARGAINING AROUND THE HEARTH
}

\author{
Robert A. Pollak \\ Working Paper 13142 \\ http://www.nber.org/papers/w13142
}
NATIONAL BUREAU OF ECONOMIC RESEARCH
1050 Massachusetts Avenue
Cambridge, MA 02138
May 2007

Robert A. Pollak is the Hernreich Distinguished Professor of Economics at Washington University in St. Louis and a Research Associate of the National Bureau of Economic Research. He wishes to thank Susan Appleton, Robert Ellickson, and Margo Schlanger for helpful comments and conversation, and Joanne Spitz for editorial assistance. Reprinted by permission of The Yale Law Journal Company and William S. Hein Company from The Yale Law Journal's The Pocket Part. Vol. 116, page 414. The views expressed herein are those of the author(s) and do not necessarily reflect the views of the National Bureau of Economic Research.

(C) 2007 by Robert A. Pollak. All rights reserved. Short sections of text, not to exceed two paragraphs, may be quoted without explicit permission provided that full credit, including $\bigcirc$ notice, is given to the source. 
Bargaining Around the Hearth

Robert A. Pollak

NBER Working Paper No. 13142

May 2007

JEL No. D1,J12,K36

\begin{abstract}
$\underline{\text { ABSTRACT }}$
In "Unpacking the Household: Informal Property Rights Around the Hearth" (Yale Law Journal, 2006) Robert Ellickson argues that as long as members of a household expect their relationship to continue, norms, rather than law, will determine allocations among them. More specifically, Ellickson argues that in "midgame" household members either ignore the "endgame" completely or, if they do take endgame considerations into account, the relevant endgame considerations are determined by norms rather than by law. This paper examines the fit between Ellickson's claims and four bargaining models that economists have used to understand interactions within household and families.
\end{abstract}

Robert A. Pollak

Washington University in St. Louis

Faculty of Arts and Sciences

and the John M. Olin School

Campus Box 1133

1 Brookings Drive

St. Louis, MO 63130-4899

and NBER

pollak@wustl.edu 
In "Unpacking the Household: Informal Property Rights Around the Hearth,” Ellickson (2006) argues that as long as members of a household expect their relationship to continue, norms, rather than law, will determine allocations among them. More specifically, Ellickson argues that in "midgame" household members either ignore the "endgame" completely or, if they do take endgame considerations into account, the relevant endgame considerations are determined by norms rather than by law. In this paper I examine the fit between Ellickson's claims and four bargaining models that economists have used to understand interactions within households and families.

The irrelevance of "small bore private law" is a theme familiar to readers of Ellickson's justly famous 1991 book, Order Without Law: How Neighbors Settle Disputes. Using the Coasian example of liability for damage caused by straying cattle, Order Without Law investigates the effect of liability rules on the behavior of ranchers and farmers in Shasta County, California. Contrary to the Coasian, "legal centralist" prediction about the importance of liability rules and property rights, Ellickson finds that norms trump law. More specifically, he finds that even in jurisdictions in which the law does not impose on ranchers responsibility for the damage their straying cattle do to crops, ranchers compensate farmers.

In "Unpacking the Household," an important recent article in the Yale Law Journal, Ellickson shifts his attention from how neighbors settle disputes to how households settle disputes. The close relationship between the book and the article is signaled by the title of the article's final part: “Order Without Law in an Ongoing Household." In the article, as in the book, Ellickson's concern is the relative importance of norms and law. His conclusion: norms, not law, are the crucial determinants of allocation within households.

Recent work in economics has emphasized bargaining power rather than transaction costs and norms as a determinant of allocation within households/families. Economists have developed a number of alternative bargaining models, each capturing a different aspect of household/family interaction. I examine the fit between these alternative bargaining models and Ellickson's claims about the unimportance of legal rules and the importance of norms. I argue that for some types of 
households/families—specifically, parents with minor children and married couples—legal rules are more important than Ellickson allows. For other types of households, his conclusion that, for transaction cost reasons, individuals organize their domestic arrangements without regard to small bore private law is surely correct.

Ellickson begins, as transaction cost analysis usually does, with Coase's (1937) famous questions about the nature of the firm. Coase asked: if markets provide efficient coordination of production activities, why do we have firms? Or, arguing the contrary point: if hierarchical firms provide efficient coordination of production activities, why do we have markets? Why not organize all production activities through one giant firm? Ellickson asks the analogous questions about households: “why don’t all adults live alone? Or, conversely, all in one huge household?”

A substantial transaction cost literature addresses Coase's questions about firms; a much smaller literature addresses the analogous questions about households. Beginning with the ownership of the dwelling unit and the role of providers of at-risk capital, Ellickson's analysis provides an important new perspective on household governance. Ellickson emphasizes the distinction between households and families, explicitly limits his analysis to households, and correctly points out that the literature is often careless about this distinction.

Using transaction cost analysis, Ellickson examines the relationship between household governance and the size and composition of households. Household governance is characterized by the absence of formal contracts. Ellickson argues that informal household governance works best when household members are few in number and linked together by ties that go beyond the household. Because people forming households prefer to "consort with intimates," households are typically kin based. The "liberal state” provides background rules guaranteeing individuals freedom of exit, and freedom of exit limits exploitation within the household. Ellickson restricts his attention to adults and does not deal with the complications presented by children. Thus, he does not consider the terms on which children can leave the household and, more seriously given his focus on adults, he does not consider the terms on which parents with minor children can exit. Yet freedom of exit would have very different implications for the ongoing relationship between parents if the law were to presumptively award custody of minor children to fathers than if it presumptively awarded custody to mothers. 
The generality and complexity of the households Ellickson considers contrast with the specificity and simplicity of the households usually considered by economists. Ellickson's analysis purports to encompass all households, from the simplest one-person and two-person households to the most complex multiperson households (e.g., students sharing a house; intentional communities such as Brook Farm, Israeli kibbutzim, or contemporary co-housing developments). For expositional purposes, Ellickson introduces what he calls the "Sitcom Household,” consisting of five persons: four generations of a family (Granny, Dad, Dad's divorced thirty-five-year-old daughter, and her seven-year-old son) and an unrelated live-in nanny.

Economists achieve specificity and simplicity by focusing on two-person households or, more precisely, on households in which only two persons play roles in household governance. The most highly developed economic analysis focuses on married couple households, but with suitable modification, the analysis can be applied to other two-person households (e.g., a cohabiting couple, a single parent and an adolescent son or daughter, or a disabled elderly parent and an adult child).

Ellickson argues that households settle disputes differently in the midgame than in the endgame:

In midgame, all participants in a household relationship by definition are currently satisfied with their shares of the surplus and anticipate that their relationship will continue. During this stage, they are likely to rely mostly on rules of their own making, such as household-specific customs and contracts, rather than on external rules provided by the legal system. Endgame commences when participants first anticipate that some or all of them soon will terminate the relationship. In endgame, the rules of the legal system are more likely to become influential. (pp. 297-298)

In his final paragraph, Ellickson returns to the limited role of small bore private law:

Legal centralists assume that private law influences events not only after things go wrong, but also before they do-that is, when people prepare for that possibility. One of my central factual premises, by contrast, has been that most people, wishing to minimize 
involvement with lawyers, structure their household arrangements beyond the shadow of private law. (p. 328)

To an economist who studies family bargaining, Ellickson's most striking claim is the irrelevance of endgame considerations in the midgame.

Ellickson's game metaphor provides a verbal and conceptual bridge between his normsbased analysis and economists' game-theoretic analysis of household/family bargaining. Four models-divorce threat bargaining, separate spheres bargaining, the core, and two-stage bargaining - capture different aspects of household/family interactions. I discuss each of these four models in turn, emphasizing the fit between each model and Ellickson's analysis.

In an important class of bargaining models, bargaining power depends on the well-being of the players at a "threat point," which corresponds to the outcome if the players fail to reach agreement. (Instead of "threat point," some authors use the terms "disagreement point," "breakdown position,” or "fallback position.”) Divorce threat and separate spheres bargaining differ only in how they specify the empirical counterpart of the threat point. The first generation of bargaining models of marriage, the divorce threat models of Manser and Brown (1980) and McElroy and Horney (1981), specified the threat point as the well-being of the players if they were to divorce. Thus, with divorce threat bargaining, midgame allocation depends on endgame considerations, including the economic and social opportunities of divorced men and women as well as the provisions of small bore private law that govern divorce and child custody.

In separate spheres bargaining, the threat point is not divorce but a "non-cooperative marriage”- "harsh words and burnt toast," in Bergstrom’s (1996) memorable phrase. Lundberg and Pollak (1993) motivate separate spheres bargaining by arguing that in many marital conflicts divorce is not a plausible threat. They assume that in the noncooperative marriage, spouses revert to traditional gender specialization that reflects gender norms. With separate spheres bargaining, allocation in midgame depends on gender norms and on the economic resources each spouse controls within the marriage, but not on endgame considerations.

Before discussing the two remaining bargaining models-the core and two-stage bargaining - I want to make a general point about the range within which all bargains acceptable to both spouses must lie. In all four of the economists' bargaining models, neither spouse would agree to an allocation he or she viewed as worse than divorce. In divorce threat and separate 
spheres bargaining, the specification of the threat point determines a unique equilibrium within this range. With divorce threat bargaining, the threat point is external to the marriage, while with separate spheres bargaining it is internal. Ellickson's conclusion that endgame considerations have little effect on midgame allocation is consistent with separate spheres but not with divorce threat bargaining.

Ellickson (2006, p. 306) claims that "gift exchange" rather than "bargained-for exchange" determines household allocation in midgame. I distinguish between a strong version of this claim, which is inconsistent with any role for bargaining power, and a weak version, which is not. The strong version of Ellickson's claim that gift exchange rather than bargained-for exchange determines household allocation asserts that norms alone determine allocation. ${ }^{1}$ The strong version implies not only the irrelevance of small bore private law and all other endgame considerations, but also denies any role for midgame bargaining power.

Empirical evidence suggests that midgame bargaining power-more specifically, control over resources within marriage-affects allocation. A "randomized experiment" in which some husbands and some wives were selected to receive income transfers would provide an ideal test of this assertion. A "natural experiment" in which some husbands or some wives received income transfers-so long as those who received the transfers were not selected on the basis of their characteristics or their prior behavior-would provide a convincing although less-than-ideal test. Changes in the British child allowance instituted by Margaret Thatcher's government in the late 1970s are just such a natural experiment. These changes had the effect of transferring substantial resources from husbands to wives in two-parent families. Lundberg, Pollak, and Wales (1997), using data on the expenditure patterns of British households, found strong evidence that this transfer of resources "from the wallet to the purse" increased expenditures on both women's and children's clothing relative to men's clothing. These increases, which were substantial and statistically significant, provide evidence that control over resources affects household expenditure patterns. Lundberg and Pollak (forthcoming 2007) summarize the evidence that control over resources affects allocation within marriage, and interpret this as

\footnotetext{
${ }^{1}$ Ellickson’s discussion in his final part, "Order Without Law in an Ongoing Household," is consistent with the strong version of his claim.
} 
evidence that bargaining power matters. These results refute the strong version of Ellickson's claim that norms alone determine the allocation of resources during midgame.

The weak version of Ellickson's claim about the absence of bargaining focuses on the process of bargaining and asserts that individuals living in the same household usually rely on implicit rather than explicit bargaining. This weak version is compatible with a significant role for bargaining power. ${ }^{2}$ Allocation within the household might reflect tacit bargaining, even if household members never engage in negotiations involving offers and counteroffers, never resort to explicit threats (e.g., of physical violence), and never even have explicit conversations about allocation.

To economists, "bargaining" is about the relationship between bargaining power and outcomes, not about the process of bargaining. For example, the bargaining power hypothesis implies that a government program such as the British child allowance that transferred resources from husbands to wives would affect allocation between spouses. More specifically, the bargaining power hypothesis predicts that such a program would result in husbands having less leisure time and households spending less on goods husbands are likely to consume (e.g., cigars and pipe tobacco). In the tradition of Milton Friedman's (1953) "The Methodology of Positive Economics," economists' bargaining models generate predictions about behavior: households behave "as if" bargaining power affects allocation. Thus, separate spheres bargaining predicts that a government program such as the British child allowance that transfers resources from husbands to wives would affect allocation within households. Divorce threat bargaining predicts that such a transfer would have no effect. And the strong version of Ellickson's norm-based gift exchange also predicts that such a transfer would have no effect.

Reciprocity is a crucial element of gift exchange. Ellickson writes: "For a process of gift exchange to be mutually beneficial, each participant must keep a (preferably rough) mental account of who has contributed what and who has received what. Because domestic gift-giving can be fitful, temporary imbalances of trade are likely to arise (p. 305).” Thus, reciprocity means more than giving a gift when it is your turn; reciprocity means giving the appropriate gift. With gift exchange, individuals keep mental accounts and are conscious of whether these accounts

\footnotetext{
${ }^{2}$ Ellickson's discussion on pages 245-247 explicitly recognizes that bargaining power may affect allocation.
} 
balance. That is, individuals within the household have a shared sense of what constitutes balance. Although this balance might be based solely on norms, as in the strong version of Ellickson's gift exchange claim, it might also reflect bargaining power. Ellickson's suggestion that the balance of trade might be rough rather than precise suggests that the gift-exchange may be compatible with multiple equilibria. Although divorce threat and separate spheres bargaining each imply a unique equilibrium, economists' third bargaining model, the core, allows multiple equilibria.

The core in a two-person game is the set of Pareto-efficient allocations that are within the range of acceptable outcomes implied by freedom of exit. Pareto efficiency is best understood in terms of its opposite, Pareto inefficiency. An allocation is Pareto inefficient if some other feasible allocation would make everyone in the household better off; an allocation is Pareto efficient if it is impossible to do so. The core, because it is compatible with a broad spectrum of allocations - indeed, every Pareto-efficient allocation in the acceptable range is an equilibriumprovides a formalization of Ellickson's suggestion that balance is rough rather than precise.

Legal rules and social norms that make freedom of exit readily available weaken the ability of individuals to make credible commitments not to exit. This idea plays a crucial role in Becker's Treatise on the Family $(1981,1991)$, in which he discusses the relationship between the risk of divorce and the willingness of spouses to make "marriage specific investments." Ellickson, in a subsection entitled "When co-occupants anticipate periods of grossly unbalanced labor contributions," acknowledges that reciprocity works best when the mental accounts remain close to balance most of the time. Two-stage bargaining models formalize this insight.

Lundberg and Pollak (2003) introduce two-stage bargaining in the context of what they call the "two-earner couple location problem." The first stage determines whether the couple moves to the husband's or to the wife's preferred city, and the second stage determines allocation within marriage conditional on the city determined at the first stage. When the spouses prefer different cities, inefficient outcomes (e.g., inefficient divorces) are possible even when the second stage game is efficient conditional on the city determined at the first stage. The crucial features of the two-earner couple location problem are that first-stage decisions affect future bargaining power 
and that spouses cannot or will not make binding agreements not to exploit their bargaining advantage. Lundberg and Pollak argue that the two-earner couple location problem provides a paradigm for an important class of problems in which big, up-front decisions affect future bargaining power. These include decisions to invest in education, to participate in the labor market, and to have children. The inability or unwillingness of family members to make binding commitments concerning future allocations implies that strategic considerations may prevent households/families from achieving Pareto-efficient outcomes.

What does the discussion of the four economists' models of household/family bargaining imply about Ellickson's claim that endgame considerations are irrelevant to midgame allocations? Ellickson's claim gains support from empirical evidence that favors separate spheres over divorce threat bargaining. The core, which implies multiple equilibria, is consistent with Ellickson's suggestion that gift exchange requires a rough rather than a precise balance of accounts. Finally, two-stage bargaining suggests that for household/family decisions involving long-term obligations that affect future bargaining power (e.g., bearing and rearing children), gift exchange, reciprocity, and freedom of exit may lead to Pareto inefficient outcomes. Such decisions may be influenced by the terms on which individuals can exit or, more precisely, by individuals' understandings of the terms on which they can exit.

Hence, in some types of households, endgame considerations may play a greater role in determining midgame allocation than Ellickson acknowledges. More specifically, the laws governing child custody and child support obligation may be important for couples with minor children, and the laws governing the division of marital property may be important for married couples. For other types of households-including the Sitcom Household-Ellickson's transaction cost analysis is surely right. In such households, allocation may depend on the individuals' perceptions of the endgame, but the endgame they envision does not involve lawyers and judges_-it is, as Ellickson writes, "beyond the shadow of private law.” 
References

Becker, Gary S., A Treatise on the Family, Cambridge: Harvard University Press, 1981;

Enlarged edition, 1991.

Bergstrom, Theodore C., "Economics in a Family Way," Journal of Economic Literature," Vol. XXIV, No. 4, (December 1996), 1903-1934.

Coase, Ronald H., "The Nature of the Firm," Economica 4:16, N.S. (November 1937), 386-405.

Ellickson, Robert C., Order without Law: How Neighbors Settle Disputes, Cambridge: Harvard University Press, 1991.

Ellickson, Robert C., "Unpacking the Household: Informal Property Rights Around the Hearth," Yale Law Journal Vol. 116, No. 2, (November 2006), 226-328.

Friedman, Milton, "The Methodology of Positive Economics," in Essays in Positive Economics, Chicago: University of Chicago Press, 1953. 3-43.

Lundberg, Shelly and Robert A. Pollak, "Separate Spheres Bargaining and the Marriage Market," Journal of Political Economy, Vol. 101, No. 6, (December 1993), 988-1010.

Lundberg, Shelly and Robert A. Pollak, "Efficiency in Marriage," Review of Economics of the Household, Vol. 1, No. 3, (September 2003), 153-168.

Lundberg, Shelly and Robert A. Pollak, "Family Decision-Making," 2007. Forthcoming in The New Palgrave Dictionary of Economics, 2nd Edition, Larry Blume and Steven Durlauf, eds. Palgrave Macmillan.

Lundberg, Shelly, Robert A. Pollak, and Terence J. Wales, "Do Husbands and Wives Pool Their Resources? Evidence from the U.K. Child Benefit," Journal of Human Resources, Vol. 32, No. 3 (Summer 1997), 463-480.

Manser, Marilyn and Murray Brown, "Marriage and Household Decision-Making: A Bargaining Analysis," International Economic Review, Vol. 21, No. 1, (February 1980), 31-44.

McElroy, Marjorie B. and Mary J. Horney, "Nash-Bargained Household Decisions: Toward a Generalization of the Theory of Demand," International Economic Review, Vol. 22, No. 2, (June 1981), 333-349. 